\title{
Hubungan Minat Mengikuti Ekstrakurikuler Pendidikan Kepramukaan dengan Kedisiplinan Anggota Gudep di Gugus X Kota Bengkulu
}

\author{
Eri Candramustika \\ Universitas Bengkulu \\ ericmratu@gmail.com
}

Lukman

Universitas Bengkulu toplukman232gmail.com

\section{Osa Juarsa}

Universitas Bengkulu juarsaosa@yahoo.com

\begin{abstract}
The purpose of this research is to analyze the relationship between extracurricular interests follow Scouting education with discipline a member Gudep found in Bengkulu City cluster of X. The quantitative approach used and the type of research that used korelasional. The population in this research is the entire members of the Gudep contained in the cluster X 332 by the amount of Bengkulu City students. The sample in this research totalled 84 students. Sampling techniques in the research of this proportionate stratified random sampling. Instrument in this study is the sheet now. Data collection techniques using question form. Data analysis techniques using test prerequisites and test hypotheses using the correlation formula product moment. The results of this research show that the value of rxy $=0.695$ with rtabel $=0.212(0.695>0.212), K P=$ $48.3 \%$, and thitung $=5.74$, with ttabel $=1.663(5.74>1.663)$. Thus, it can be concluded that there is a significant relationship between interest in extracurricular education follow Scouting with the discipline of members in Gudep cluster X city of Bengkulu.
\end{abstract}

Keywords: Education, discipline, interest in Scouting.

\begin{abstract}
Abstrak
Tujuan dari penelitian ini adalah untuk menganalisis hubungan antara minat ekstrakurikuler mengikuti pendidikan Kepramukaan dengan disiplin anggota Gudep yang ditemukan di cluster Kota X Bengkulu. Pendekatan kuantitatif yang digunakan dan jenis penelitian yang digunakan korelasional. Populasi dalam penelitian ini adalah seluruh anggota Gudep yang terkandung dalam klaster X 332 dengan jumlah siswa Kota Bengkulu. Sampel dalam penelitian ini berjumlah 84 siswa. Teknik pengambilan sampel dalam penelitian proporsional stratified
\end{abstract}


random sampling ini. Instrumen dalam penelitian ini adalah lembaran sekarang. Teknik pengumpulan data menggunakan formulir pertanyaan. Teknik analisis data menggunakan prasyarat uji dan uji hipotesis menggunakan rumus korelasi product moment. Hasil penelitian ini menunjukkan bahwa nilai rxy $=0,695$ dengan rtabel $=0,212(0,695>$ $0,212), \mathrm{KP}=48,3 \%$, dan thitung $=5,74$, dengan ttabel $=1,663(5,74>$ 1,663). Dengan demikian, dapat disimpulkan bahwa ada hubungan yang signifikan antara minat mengikuti pendidikan ekstrakurikuler mengikuti Kepramukaan dengan kedisiplinan anggota di Gudep cluster $\mathrm{X}$ kota Bengkulu.

Kata kunci: Pendidikan, disiplin, minat Kepramukaan.

\section{Pendahuluan}

Disiplin adalah salah satu sarana dalam upaya pembentukan kepribadian dan merupakan kunci keberhasilan, sebab dengan tingkat kedisiplinan tinggi maka tingkat konsentrasi dalam melaksanakan kegiatan meningkat. Namun seiring berkembangnya zaman, nilai-nilai kedisiplinan semakin memudar. Hal ini terbukti saat membuat janji dengan orang lain, datang terlambat.Selain itu banyak siswa yang belum paham tentang arti dari kedisiplinan dan pembina pramuka belum memberikan sanksi yang tegas terhadap siswa yang belum disiplin. Salah satu contoh perilaku siswa yang menunjukkan sikap tidak disiplin yaitu melanggar aturan gugus depan.

Dari hasil observasi yang dilakukan oleh peneliti di gudep yang terdapat di gugus X Kota Bengkulu, yaitu gudep 06.021-06.022 dan 06.037-06.038 terdapat banyak permasalahan yang ditemukan pada saat latihan kepramukaan seperti tidak membawa peralatan lengkap, tidak menggunakan atribut yang lengkap dan umumnya mereka selalu ribut saat latihan. Sehingga hal tersebutlah yang membuat kegiatan ekstrakurikuler pendidikan kepramukaan tidak berjalan dengan baik dan khidmat.

Disiplin dibentuk saat latihan kepramukaan dilaksanakan untuk selanjutnya dibiasakan dan diterapkan dalam kehidupan kehidupan bermasyarakat dan bersosialisasi dengan banyak orang. Disiplin merupakan suatu tindakan yang menunjukkan perilaku tertib dan patuh pada berbagai ketentuan dan peraturan (Kemendiknas : 2010). Dari penyataan tersebut dapat diketahui bahwa seseorang yang mematuhi dan taat pada seluruh peraturan yang dibuat oleh suatu lembaga adalah manusia yang disiplin. Sedangkan, manusia yang tidak mematuhi atau melanggar seluruh peraturan yang telah dibuat adalah manusia tidak disiplin.

Seorang anggota pramuka dikatakan disiplin saat datang latihan tepat waktu, menyelesaikan tugas yang di berikan oleh pembina pramuka, berpakaian dan menggunakan atribut lengkap saat latihan dilaksanakan juga masih banyak lainnya. Namun pada kenyataannya, banyak anggota pramuka yang tidak memenuhi beberapa syarat tersebut. Terbukti oleh hasil pengamatan yang dilakukan oleh peneliti pada saat latihan kepramukaan di gugus depan 06.021-06.022 banyak anggota yang tidak tepat waktu sehingga datang terlambat, ada juga yang tidak menggunakan atribut lengkap dengan alasan lupa membawa dan terburu-buru sehingga tertinggal di rumah. Dengan alasan klasik seperti yang disampaikan beberapa anggota tersebut, pembina akan memberikan hukuman sebelum mereka mengikuti latihan rutin bersama teman-teman lainnya untuk memberikan efek jera bagi mereka yang terlambat agar tidak di ulangi di kemudian hari.

Banyak anggota pramuka yang jera dan tidak mengulanginya di minggu selanjutnya, namun banyak pula yang masih melakukan kesalahan tersebut. 
Dengan mengulangi kesalahan yang sama, dapat disimpulkan bahwa manusia tersebut tidak serius mengikuti kegiatan ekstrakurikuler tersebut. Tidak serius disini di artikan sebagai sikap kurang berminat pada kegiatan tersebut. Saat anggota pramuka memilih beberapa kegiatan ekstrakurikuler yang ingin di ikutinya hendaknya diplih berdasarkan peminatan. Karena tonggak awal bertahan dalam suatu organisasi kegiatan adalah karena suka.

Faktor yang mempengaruhi disiplin seorang siswa menurut Haditono (Ahmad Faiz, 2008:49), yakni: (1) anak itu sendiri, (2) sikap pendidik, (3) lingkungan, dan (4) tujuan. Faktor yang pertama yakni anak itu sendiri, dalam menanamkan kedisiplinan faktor anak harus diperhatikan, mengingat anak memiliki potensi, kepribadian dan minat yang berbeda antara satu dengan yang lain. Pemahaman terhadap minat anak secara cermat dan tepat akan berpengaruh terhadap keberhasilan penanaman kedisiplinan. Dengan memahami minat anak, maka pendidik telah berkontribusi dalam meningkatkan kedisiplinan anak.

Faktor yang kedua yakni sikap pendidik, Sikap pendidik yang bersikap baik, penuh kasih sayang, memungkinkan keberhasilan penanaman kedisplinan pada anak. Hal ini dimungkinkan karena pada hakikatnya anak cenderung lebih patuh kepada pendidik yang bersikap baik. Sebaliknya, sikap pendidik yang kasar, keras, tidak peduli, dan kurang wibawa akan berdampak terhadap kegagalan penanaman kedisiplinan dalam kegiatan kepramukaaan.Faktor yang ketiga yakni lingkungan, lingkungan akan mempengaruhi proses dan hasil pendidikan. Lingkungan yang baik akan menghasilkan anak-anak yang baik, sebaliknya lingkungan yang tidak baik akan menghasilkan anak-anak dengan watak yang tidak baik.

Faktor yang keempat yakni tujuan, tujuan yang dimaksud disini adalah tujuan yang berkaitan dengan penanaman kedisiplinan. Agar penanaman kedisiplinan kepada siswa dapat berhasil, maka tujuan tersebut harus ditetapkan dengan jelas, termasuk penentuan kriteria pencapaian tujuan penanaman kedisiplinan. Faktor yang mempengaruhi disiplin seorang siswa salah satunya adalah anak itu sendiri, dimana untuk menanamkan kedisiplinan faktor anak harus diperhatikan, mengingat anak memiliki potensi, kepribadian dan minat yang berbeda antara satu dengan yang lain. Pemahaman terhadap minat anak secara cermat dan tepat akan berpengaruh terhadap keberhasilan penanaman kedisiplinan.

Apabila seorang anak tidak menyukai hal-hal dalam kegiatan kepramukaan secara otomatis mereka tidak akan mengikuti aturan yang berlaku pada gugus depan, itu berarti anak tersebut tidak memiliki minat dalam mengikuti ekstrakurikuler pendidikan kepramukaan. Minat anak akan nampak apabila mereka secara suka rela mengikuti kegiatan ekstrakurikuler pendidikan kepramukaan ini tanpa ada beban dan keterpaksaan. Minat merupakan modal awal anak saat memilih suatu ekstrakurikuler yang akan di ikutinya. Minat memiliki arti kecenderungan hati yang tinggi terhadap sesuatu, perhatian, kesukaan (Pusat Bahasa Depdiknas:2008). Jadi, harus ada sesuatu yang ditimbulkan, baik dari dalam dirinya maupun dari luar untuk menyukai sesuatu. Hal ini menjadi sebuah landasan penting untuk mencapai keberhasilan suatu hal karena adanya minat, seseorang menjadi termotivasi dan tertarik untuk melakukan sesuatu yang disenanginya.

Dengan memilih sesuai minat dan kemampuan, maka siswa tersebut secara tidak langsung telah mendengarkan kata hatinya. Siswa yang telah memilih ekstrakurikuler Pendidikan Kepramukaan tanpa paksaan akan lebih mudah menyerap setiap kegiatan yang diadakan pada ekstrakurikuler tersebut dan akan lebih dapat mengamalkan nilai-nilai serta kode kehormatan pramuka dalam lingkungan sekolah, keluarga dan masyarakat. Berbeda apabila siswa mengikuti ekstrakurikuler Pendidikan Kepramukaan dengan paksaan bukan berdasarkaan minat siswa. Maka siswa tersebut tidak akan menyerap nilai-nilai yang terkandung 
dalam Gerakan Pramuka tersebut sehingga dalam pelaksanaannya pun siswa tersebut tidak terlalu mengikuti kegiatan-kegiatan yang dilaksanakannya.

\section{Metode}

Jenis penelitian Kuantitatif dengan metode penelitian Korelasional. Pelaksanaan penelitian ini menggunakan angket dengan skala likert. Penelitian ini dilakukan untuk mengetahui hubungan minat mengikuti ekstrakurikuler pendidikan kepramukaan dengan kedisiplinan anggota gudep di gugus X Kota Bengkulu.

Penelitian ini dilakukan dengan membagikan angket kepada anggota gudep 06.02106.022 dan 06.037-06.038 yang tidak termasuk kedalam sampel untuk uji coba instrument terlebih dahulu. Setelah melakukan uji coba istrumen, peneliti menghitung data validitas dan reliabilitas. Peneliti membagikan angket kepada anggota gudep 06.021-06.022 dan 06.037-06.038 dengan angket yang sudah valid dan reliable. Peneliti menghitung normalitas, homogenitas, uji korelasional dan uji t signifikan.

Dalam penelitian ini, yang menjadi populasi seluruh anggota gudep yang ada di gugus X Kota Bengkulu, yang terdiri dari gudep 06.021-06.022 dan 06.037-06.038. Seluruh populasi berjumlah 332 orang siswa.

Teknik pengambilan sample menggunakan proportionate stratified random sampling, Sehingga untuk menentukan sampel secara proporsional, responden yang di ambil pada setiap jenjang kelas untuk keperluan penelitian ini adalah $25 \%$. Setiap jenjang kelas di ambil 25\% dari jumlah populasi untuk menentukan berapa banyak responden yang digunakan untuk menjadi sampel pada penelitian ini. Sejalan dengan pendapat yang kemukakan oleh Arikunto (2006: 134) jika subjek yang diteliti kurang dari 10, maka lebih baik diambil semuanya sebagai sampel, sehingga penelitiannya merupakan penelitian populasi. Tetapi jika subjeknya besar dapat diambil antara $10 \%-15 \%$ atau $20 \%-25 \%$ atau lebih. Sehingga jumlah sampel pada penelitian ini adalah 84 orang anggota pramuka.

Instrumen yang digunakan dalam penelitian ini adalah angket dengan skala likert. Dalam penelitian ini ada dua instrumen yaitu angket minat dan angket kedisiplinan anggota gudep dengan 4 pilihan. Instrumen angket minat terdiri dari 25 pernyataan. Sedangkan Instrumen angket kedisiplinan anggota gudep terdiri dari 30 pernyataan Sebelum dilakukan uji coba instrumen, terlebih dahulu dilakukan validasi oleh ibu Dr. Puspa Djuwita, M.Pd. selaku dosen Universitas Bengkulu. Berdasarkan hasil validasi semua pernyataan layak untuk di uji cobakan.

Berdasarkan hasil uji coba instrumen, diperoleh untuk angket minat 19 pernyataan dikatakan valid dan reliable, serta untuk angket kedisiplinan anggota gudep 25 pernyataan dikatakan valid dan reliable. Dapat disimpulkan instrumen layak untuk digunakan sebagai instrumen penelitian.

Teknik pengumpulan data pada penelitian ini menggunakan angket dengan skala likert. Peneliti menggunakan dua angket yang akan diujicobakan, yaitu angket minat dan angket kedisiplinan anggota gudep. Kedua angeket diujicobakan dengan masingmasing terdiri dari 25 dan 30 pernyataan. Setelah kedua angket diujicobakan kemudian peneliti menghitung validitas dan reliabelitas.

Angket minat dengan 19 pernyataan yang valid dan reliable, dan angket kedisiplinan anggota gudep 25 pernyataan yang valid dan reliable. Kemuadian kedua angket tersebut menjadi alat untuk mengumpulkan data, yang akan dibagikan kepada seluruh anggota gudep yang terdapat di gugus X Kota Bengkulu. 
Analisis data yang dilakukan meliputi analisis deskriptif yaitu penyajian data melalui tabel, perhitungan skor rata-rata (mean), dan varian; analisis uji prasyarat yaitu dengan melakukan uji normallitas dan uji homogenitas, dan uji analisis korelasi, sumbangan, dan uji signifikan korelasi.

\section{Hasil}

Penelitian ini bertujuan untuk menganalisis hubungan antara minat mengikuti ekstrakurikuler pendidikan kepramukaan dengan kedisiplinan anggota Gudep yang terdapat di gugus X Kota Bengkulu. Pada gugus X Kota Bengkulu, terdapat 2 gudep yaitu gudep 06.021-06.022 dan 06.037-06.038 yang anggota gudepnya berjumlah 332 anak. Penelitian ini dilaksanakan pada tanggal 9 Mei 2018, dengan jumlah sampel sebanyak 84 siswa yang merupakan anggota dari kedua gudep tersebut. Sebelumnya di adakan uji coba instrumen terlebih dahulu untuk mengetahui apakah butir pernyataan dari kedua variabel tersebut valid dan reliabel. Setelah dinyatakan valid dan reliabel, maka dilaksanakanlah penelitian di gudep 06.021-06.022 dan 06.03706.038. Berdasarkan hasil penelitian yang telah dilakukan membuktikan bahwa terdapat hubungan yang signifikan antara variabel minat dengan variabel kedisiplinan anggota gudep yang terdapat di gugus X Kota Bengkulu.

Hal ini menunjukkan bahwa kedisiplinan seorang siswa dalam mengikuti kegiatan ekstrakurikuler pendidikan kepramukaan berkaitan dengan minat siswa tersebut. Adanya hubungan tersebut dapat ditunjukkan dari perolehan perhitungan korelasi product moment atau rhitung sebesar 0,695 (lampiran 13 halaman 124) dengan nilai rtabel sebesar 0,212 (lampiran 13 halaman 124). Sehingga dapat diketahui bahwa antara variabel minat dan variabel kedisiplinan mempunyai hubungan karena rhitung $>$ rtabel $(0,695>0,212)$.

Berdasarkan hasil perhitungan yang dilakukan menunjukkan bahwa antara kedua variabel tersebut mempunyai hubungan yang kuat, karena berada pada rentang antara 0,60-0,79. Hal ini sesuai dengan pendapat Hurlock (2003:166) yang menyatakan bahwa minat yang dikembangkan esangat mempengaruhi perilaku siswa. Artinya minat seseorang dapat mempengaruhi perilaku siswa salah satunya menjadi disiplin. Di sekolah siswa di bebaskan untuk memilih salah satu ekstrakurikuler yang di tekuninya. Ada berbagai macam ekstrakurikuler salah satunya adalah pendidikan kepramukaan. Apabila seorang siswa telah memilih untuk ikut dalam ekstrakurikuler kepramukaan, artinya siswa tersebut tertarik dengan kegiatan dalam kepramukaan dan bisa dikatakan minatnya tinggi.

Seorang siswa yang tidak tertarik dengan kegiatan di dalam ekstrakurikuler pendidikan kepramukaan cenderung akan cepat bosan dan malas-malasan. Rasa bosan inilah yang mendorong siswa untuk melakukan aktivitas lain sehingga menurunkan tingkat kedisiplinan yang ada pada diri siswa. Sebaliknya, jika siswa tertarik dengan ekstrakurikuler pendidikan kepramukaan, maka siswa akan cenderung memperhatikan dan mengikuti kegiatan-kegiatan tersebut dengan disiplin.

Melalui kegiatan kepramukaan siswa akan mendapat pengalaman berharga yang sangat bermanfaat bagi dirinya sendiri. Kedisiplinan dalam kegiatan ekstrakurikuler pendidikan kepramukaan dapat di identifikasi dengan sikap siswa ketika mengikuti jalannya kegiatan tersebut. Kedisiplinan tersebut salah satunya ditandai dengan sikap yang bersungguh-sungguh ketika mengikuti jalannya kegiatan. Hal ini sesuai dengan pendapat dari (Naim, 2012 :43) yang menyebutkan bahwa kedisiplinan dalam belajar salah satunya ditandai dengan sikap yang bersungguh-sungguh dalam mengikuti pembelajaran Kesungguhan ini juga dapat dilihat apabila siswa tersebut mencerminkan indikator kedisiplinan. 
Indikator kedisiplinan menurut Kemendiknas (2010) dalam pengembangan pendidikan budaya karakter bangsa diantaranya: (1) menyelesaikan tugas pada waktunya; (2) saling menjaga dengan teman agar semua tugas-tugas terlaksana dengan baik; (3) selalu mengajak teman menjaga ketertiban; (4) mengingatkan teman yang melanggar peraturan dengan kata-kata sopan dan tidak menyinggung; (5) berpakaian sopan dan rapi; (6) mematuhi aturan gugus depan. Indikator inilah yang digunakan dalam penelitian ini, siswa yang mengikuti kegiatan ekstrakurikuler pendidikan kepramukaan dengan sungguh-sungguh akan mencerminkan indikator-indikator kedisiplinan tersebut.

Dengan demikian, indikator kedisiplinan di atas menunjukkan bahwa siswa tersebut memiliki minat dalam mengikuti ekstrakurikuler pendidikan kepramukaan. Sehingga minat mempengaruhi kedisiplinan dalam diri siswa karena melakukan kegiatan tersebut dengan suka rela, ikhlas dan penuh semangat. Apabila seorang siswa mematuhi seluruh aturan gudep dan menjalankannya dengan penuh semangat dan sukarela maka minat anak tersebut terhadap ekstrakurikuler pendidikan kepramukaan tinggi.

Teori minat belajar yang dikemukakan oleh Suradi (Munawwarah, 2017:97) juga menyatakan bahwa adanya minat belajar yang tinggi, maka semangat belajar juga akan tinggi. Sama halnya dalam belajar, dalam mengikuti kegiatan esktrakurikuler pendidikan kepramukaan pun apabila seorang siswa tersebut mempunyai minat yang tinggi dalam mengikuti jalannya kegiatan didalam ekstrakurikuler maka siswa tersebut pun memiliki semangat yang tinggi.

Semangat yang tinggi akan menjadikan siswa lebih memperhatikan, tekun, dan mengikuti kegiatan sesuai dengan aturan yang diberlakukan. Siswa yang memiliki semangat tinggi cenderung akan mengikuti kegiatan dengan seksama, siswa tidak akan meninggalkan kegiatan tanpa izin, dan akan sungguh-sungguh dalam memperhatikan petunjuk dan pengarahan yang diberikan oleh pembina pramuka. Semangat yang tinggilah yang akan menumbuhkan kedisiplinan dalam mengikuti kegiatan. Selain minat, ekstrakurikuler pendidikan kepramukaan ini juga mempunyai tujuan salah satunya membentuk disiplin seorang pramuka sehingga siswa yang terlibat dalam ekstrakurikuler tersebut juga mendapat pelatihan untuk membentuk disiplin diri.

Tabel 1. Contoh cara menyajikan tabel.

\begin{tabular}{lcc}
\multicolumn{1}{c}{ Deskripsi } & Minat & Kedisiplinan \\
Nilai Tertinggi & 76 & 101 \\
Nilai Terendah & 51 & 54 \\
Jumlah & 5290 & 7471 \\
Rata-rata & 62,97 & 88,90 \\
Varian & 10,58 & 5,36 \\
Uji Normalitas & & \\
X2 hitung & $-71,573$ & $-177,279$ \\
X2 tabel & 12,592 & 12,592 \\
Uji Homogenitas & & 1,97 \\
F hitung & & 3,96 \\
F tabel & & \\
Uji Hipotesis & & 5,74 \\
t hitung & & 1,663 \\
t tabel & & \\
\hline
\end{tabular}




\section{Pembahasan}

Berdasarkan penelitian ini, benar bahwa minat akan mempengaruhi kedisiplinan anak dalam kegiatan kepramukaan. Selain minat, ekstrakurikuler pendidikan kepramukaan ini juga mempunyai tujuan salah satunya membentuk disiplin seorang pramuka sehingga siswa yang terlibat dalam ekstrakurikuler tersebut juga mendapat pelatihan untuk membentuk disiplin diri.

Seperti yang diungkapkan oleh Hidayat (2012:20) bahwa kegiatan ekstrakurikuler pendidikan kepramukaan mempunyai tujuan untuk membangun akhlak siswa bangsa yang baik, berbudi pekerti, berpikir positif, tangguh, percaya diri, mandiri, disiplin, inovatif, dan rukun serta memiliki keseitiakawanan. Kemudian diperkuat dengan tujuan dari Gerakan Pramuka dalam Undang Undang Republik Indonesia Nomor 12 Tahun 2010 Pasal 4 Tentang Gerakan Pramuka yang menyatakan bahwa kegiatan ekstrakurikuler pendidikan kepramukaan dilakukan untuk membentuk setiap anggota pramuka agar memiliki kepribadian yang beriman, bertakwa, berakhlak mulia, berjiwa patriotik, taat hukum, disiplin, menjunjung tinggi nilainilai luhur bangsa, dan memiliki kecakapan hidup sebagai kader bangsa dalam menjaga dan membangun Negara Kesatuan Republik Indonesia, mengamalkan Pancasila, serta melestarikan lingkungan hidup. Sehingga dalam hal ini ekstrakurikuler pendidikan kepramukaan juga menjadi wadah yang sangat tepat untuk membentuk karakter dan watak seseorang menjadi lebih baik.

\section{Simpulan}

Berdasarkan penelitian maka diperoleh hasil dari perhitungan korelasi dengan rhitung sebesar 0,695 dan rtabel sebesar 0,212, dengan taraf signifikan 5\% dan $\alpha=$ 0,05 sehingga rhitung $\geq$ rtabel, hal ini berarti Ha diterima dan H0 ditolak yaitu terdapat hubungan antara minat dengan kedisiplinan anggota gudep yang terdapat di gugus X Kota Bengkulu. Artinya semakin berminat seseorang dalam mengikuti ekstrakurikuler pendidikan kepramukaan maka semakin tinggi disiplinnya, sebaliknya semakin tidak berminat seseorang dalam mengikuti ekstrakurikuler pendidikan kepramukaan maka semakin rendah disiplinnya.

\section{Saran}

Berdasarkan hasil penelitian, maka peneliti memberikan saran sebagai berikut.

1. Bagi pembina pramuka, ketika mengadakan latihan ekstrakurikuler pendidikan kepramukaan harusnya mengikuti aturan yang ada dalam undang-undang mengenai kepramukaan.

2. Bagi peneliti selanjutnya diharapkan untuk melakukan penelitian lanjutan namun dapat dihubungkan dengan nilai karakter lain.

\section{Referensi}

Arikunto, S. 2013. Prosedur Penelitian Suatu Pendekatan Praktik. Jakarta: Rineka Cipta.

Depag RI. 2004. Kegiatan Ekstrakurikuler Pendidikan Agama Islam Pada Sekolah Umum dan Madrasah, Jakarta: Departemen Agama RI.

Depdiknas, 2008. Kamus Besar Bahasa Indonesia Pusat Bahasa. Jakarta: Gramedia Pustaka Media.

Djaali. 2011. Psikologi Pendidikan. Jakarta: Bumi Aksara. 
Gunawan, H. 2012. Pendidikan Karakter Konsep dan Implementasinya. Bandung: Alfabeta.

Hidayat, H. ,\& Insan , S. 2012. Pendidikan Karakter Budaya Bangsa. Bandung: Gema Buku Nusantara.

Hurlock, E. 2003. Psikologi Perkembangan. Jakarta: Penerbit Erlangga

Jahja, Y. 2011. Psikologi Perkembangan. Jakarta: Kencana Prenada Media Group.

Kartini, T. 2007 Penggunaan Metode Role Playing Untuk Meningkatkan Minat Siswa dalam Pembelajaran Pengetahuan Sosial di Kelas V SDN Cileunyi I Kecamatan Cileunyi Kabupaten Bandung. Bandung: Universitas Pendidikan Indonesia

Kemendiknas. 2010. Bahan Pelatihan Pengembangan Pendidikan Budaya dan Karakter Bangsa, Jakarta: Badan Peneltian dan Pengembangan Pusat Kurikulum.

Mikarsa, H.L. et al.. 2009. Pendidikan Anak Di SD, Jakarta: Universitas Terbuka.

Munawarrah, S. 2017. Hubungan Minat Dan Efikasi Diri Dengan Kedisiplinan Belajar PKN Siswa Kelas IV SD N Sekecamatan Pengasih Kabupaten Kulon Progo DIY. Yogjakarta: Universitas Negeri Yogyakarta

Munir, M. 2014. Buku Sakti Pramuka, Semarang: Salmahat Publishing Permendikbud. Kurikulum 2013 Kegiatan Ekstrakurikuler Pada Pendidikan

Dasar dan Pendidikan Menengah, Jakarta:Departemen Pendidikan dan Kebudayaan.

Pratiwi, W. 2010 Pengaruh Pergaulan Teman Sebaya Terhadap Minat Belajar Pendidikan Kearganegaraan Siswa Kelas V SD 6 Wonosari. Yogyakarta: Universitas Negeri Yogyakarta

Riduwan. 2013. Dasar-dasar Statistika. Bandung: Alfabeta.

Rosyadi. A., F., A. 2012. Pengaruh Minat Mengikuti Kegiatan Ekstrakurikuler Kepramukaan Terhadap Kedisiplinan Pada Siswa Kelas V SD Se Gugus II Kecamatan Pengasih Kabupaten Kulon Progo, Yogjakarta: Universitas Negeri Yogyakarta

Setyorini. D., E. 2016. Pengaruh Ekstrakurikuler Kepramukaan Terhadap Kedisiplinan Siswa SD Negeri Gugus Cakra Kecamatan Ngaliyan Kota Semarang, Semarang : UNNES

Slameto. 2010. Belajar dan Faktor-faktor yang Mempegaruhinya. Jakarta: Rineka Cipta.

Sugiyono. 2011. Metode Penelitian Pendidikan Pendekatan Kuantitatif, Kualitatif, dan R\&D, Bandung: CV. Alfa Beta.

Sunardi, A., B. 2006. Boyman, Ragam Latihan Pramuka. Bandung: Nuansa Muda.

Tim Esensi. 2012. Mengenal Gerakan Pramuka. Jakarta : Erlangga Group.

Tu'u, T. 2004. Peran Disiplin Pada Perilaku dan Prestasi Siswa. Jakarta: Gramedia Widiasarana Indonesia 
Winarni, E., W. 2011. Penelitian Pendidikan. Bengkulu: Unit Penerbitan FKIP Universitas Bengkulu.

Zuriah, N. 2007. Pendidikan Moral dan Budi Pekerti Dalam Perspektif Perubahan, Jakarta: Bumi Aksara 